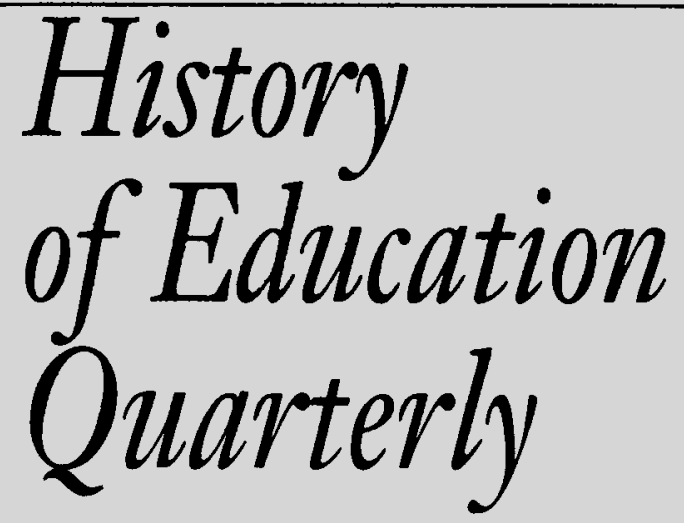

The History of Education Quarterly publisho:

- Articles

- Documents

- Debates on important issues in the history of education

- Retrospectives

- Research notes

- Essay reviews

- Book reviews

- Film reviews

Topics span the history of education, both formal and nonformal, including the history of childhood, youth, and the family. These subjects are not limited to any time period and are universal ithen scope. The Quarterly is published in cooperation with the College of Education, Slippery Rock University of Pennsylvania.

\title{
The History of Education Society
}

Individual subscription to the Quarterly includes membership in the History of Education Society. The Society is an international organization that seeks to encourage research in the history of education, to improve the teaching of the history of education, to promote the preservation of source materials in history of education, and to interest the educational profession and the general public in the value of the historical perspective in the making of educational policy.

Subscription rates (per calendar year only):

$\begin{array}{lll} & \text { US } & \text { Non-US } \\ \text { Individual (Non-Student) } & \$ 40 & \$ 47 \\ \text { Student } & \$ 20 & \$ 27 \\ \text { Institutions } & \$ 77 & \$ 84\end{array}$

Please address all subscription orders to

HISTORY OF EDUCATION QUAR'TERLY

220 McKay Education Building

College of Education

Slippery Rock University

Slippery Rock, PA 16057-1320 